\title{
Adult Giant Cell Glioblastoma
}

National Cancer Institute

\section{Source}

National Cancer Institute. Adult Giant Cell Glioblastoma. NCI Thesaurus. Code C68702.

A giant cell glioblastoma occurring in adults. 